FACTA UNIVERSITATIS

Series: Physical Education and Sport, Vol. 18, No 2, 2020, pp. 371 - 380

https://doi.org/10.22190/FUPES200116034J

Research article

\title{
CHANGES IN BODY COMPOSITION AND MUSCLE FITNESS DURING THE OFF-SEASON PERIOD IN YOUNG SOCCER PLAYERS
}

\author{
UDC 796.332.012
}

\section{Marko Jezdimirović, Anđela Đošić, Stefan Đorđević, Tomislav Okičić}

\author{
Faculty of Sport and Physical Education, University of Niš, Niš, Serbia
}

\begin{abstract}
The aim of this research was to examine the effects of a 6-week off-season period on body composition and muscle fitness in young soccer players. A total of 48 young soccer players, randomly selected for the experimental group-EG $(n=24 ;$ Age: 16.83 \pm 1.14 years; Height: $175.35 \pm 6.68 \mathrm{~cm})$ and control group-CG $(n=24 ;$ Age: $16.80 \pm 1.19$ years; Height: $178.18 \pm 6.97 \mathrm{~cm})$ took part in this research. The variables of body composition (body mass, body fat mass and BMI) and muscle fitness (CMJ, CMJAS, $20 \mathrm{~m}$ sprint, slalom test and slalom test with ball) were measured. The first testing session (TS1) took place immediately after the end of the competition period. The second testing session (TS2) was after 2 weeks and the third testing session (TS3) was after 6 weeks from the beginning of the preparation period. Statistically significant differences were found after TS2 and TS3 in all the variables $(p<0.05)$ except in the variables of agility (slalom test and slalom test with a ball) in CG. A significant difference in the experimental group after TS2 was found in the 20m sprint $(p<0.05)$ and after TS3 in body mass ( $p<0.05)$, body fat mass ( $p<0.05), B M I(p<0.05)$ and the $20 m$ sprint $(p<0.05)$. An effect size analysis showed significant increases after TS2 between $E G$ and $C G$ in the variable body fat mass (ES=-0.73, moderate) and significant decreases in the variable CMJAS (ES=0.60, moderate). Significant increases after TS3 between $E G$ and $C G$ were found in the variable body fat mass ( $E S=-0.93$, moderate) and significant decreases in both the variable of jumping performance CMJ (ES=0.81, moderate) and CMJAS (ES=0.91, moderate).
\end{abstract}

Key words: Body Composition, Muscle Fitness, Off-Season Period, Detraining

Received January 16, 2020/ Accepted May 21, 2020

Corresponding author: Marko Jezdimirović

Faculty of Sport and Physical Education, University of Niš, Čarnojevića 10a, 18000 Niš, Serbia

Phone: + $38118510900 \bullet$ E-mail: jezda1988@ gmail.com

C을 2020 by University of Niš, Serbia | Creative Commons License: CC BY-NC-ND 


\section{INTRODUCTION}

Soccer is one of the most complex sports in the world, being played in every country without exception, which depends on many variables such as body composition muscle fitness and others (Tumilty, 1993). Depending on sport to sport, body composition is different due to performance expectations and specific training (Carbuhn, Fernandez, Bragg, Green, \& Crouse, 2010). The technical skills and physical fitness of each player in soccer significantly affect match performance (Kutlu, Yapıcı, Yoncalık, \& Çelik, 2012) and the use of both of these skills in training would produce an extremely effective performance in a game such as soccer (Little \& Williams, 2007).

Each soccer season is generally based on three periods: the preparation period, competition period and off-season or transition period. In most important soccer leagues, a standard season lasts approximately 10-11 months, and they have only one cycle of these periods, but in some European countries, national championships are played on the principle of autumn-spring. For this reason, these leagues contain two cycles of the preparation, competition and off-season (transition) period. The off-season period can last for about 4-7 weeks for teams that do not participate in the top-class soccer league, and coaching during this period comes down to the individual training of the players themselves (Slettaløkken \& Rønnestad, 2014). In a game such as soccer, players during the off-season period most often participate in a periodized strength and conditioning program to maintain their performance (Minett, Binkley, Weidauer, \& Specker, 2017).

The transition or off-season period is a period of reduced stress and a very important time to start the recovery of mental and physical performance after an exhausting competition season (García-Pallarés, García-Fernández, Sánchez-Medina, \& Izquierdo, 2010). This phase of reduction or complete training cessation after the end of the competitive season has been defined as detraining (Mujika \& Padilla, 2000a) and can be divided into short term - less than 4 weeks, and long term - more than 4 weeks (Mujika, \& Padilla, 2000b). At the start of the preparation period, the effects of non-training can affect how players prepare during this phase and it can be determined how much detraining affects the performance of soccer players (Kraemer et al., 2004).

In soccer, there are only a few papers that focused on the off-season period. The research shows that recreational players and untrained individuals in a period of three to six weeks of non-training during the transitional period do not show any changes in the variables of aerobic capacity and muscle strength (Mujika \& Padilla, 2000b; Izquierdo et al., 2007). On the contrary, a decrease in physical fitness is logical after such a period in professional athletes who have a relatively higher level of physical fitness than recreational athletes (Mujika \& Padilla, 2000a; Koundourakis et al., 2014). The significance of this research is to see how long players can be passive, whether the optimal break of two weeks is enough to not affect their form and what the differences are in body composition and muscle fitness between the players who spend their transition period passively and those who practice at least three times a week, including high intensive interval training, strength exercise training and training of small sides games. The aim of this research was to examine the effects of 6-week detraining on body composition and muscle fitness during the offseason period in young soccer players. 


\section{METHODS}

\section{The sample of participants}

Forty-eight male young soccer players participated in this study and were divided into two groups: the experimental group (EG) consisted of 24 participants (Age: 16.83 \pm 1.14 years; Height: $175.35 \pm 6.68 \mathrm{~cm}$ ) and the control group (CG) which also consisted of 24 participants (Age: $16.80 \pm 1.19$ years; Height: $178.18 \pm 6.97 \mathrm{~cm}$ ). Healthy, non-injury participants were included in this research over a period of six months. The participants voluntarily took part in this research which was carried out in accordance with the Declaration of Helsinki. Approval from the parents/guardians and from the club was obtained for all the participants, as during the course of this research they were under 18 (age rank: 15-18 years). All the participants, parents and clubs were informed of the purpose of the investigation.

\section{Testing protocol}

The first testing session (TS1) or initial measurement took place immediately after the end of the competition period. The second testing session (TS2) or transit measurement was after 2 weeks, and the third testing season (TS3) or final measurement was at the beginning of the preparation period for the forthcoming season 6 weeks after the program. For all the test sessions, the participants were instructed to avoid any activities for a 24-hour period before their lab visit. Before testing, the participants performed a basic 20-minute warm-up protocol consisted of $10 \mathrm{~min}$ of light running and $10 \mathrm{~min}$ of dynamic stretching. All tests were performed on an artificial grass sports field and each testing session had an identical execution protocol.

The experimental group of soccer players followed the special training program (active period) while the control group did not participate in any training program (passive period) during the six weeks in the off-season period. The experimental group performed a total of 18 trainings $(3 \times 6)$ in the off-season period. Each week training order was the same, with a standard warm-up procedure following high-intensity interval training specially designed for each participant (HIIT), strength exercises or small-sided games (SG) with proper intensity. The intensity of training was monitored using polar heart rate monitors (Polar Team Pro; Polar Electro, Kempele, Finland) and supervised by team coaches.

\section{The sample of variables}

Body composition

During all the testing sessions, measurements of body mass $(\mathrm{kg})$, body fat mass $(\mathrm{kg})$ and Body Mass Index-BMI $\left(\mathrm{kg} / \mathrm{m}^{2}\right)$ were taken for each participant - using a multi-frequency bioelectrical impedance analyzer (InBody 770, Biospace Co. Ltd, Seoul, Korea). Measurements of body height were carried out with an anthropometer to within a $0.1 \mathrm{~cm}$ (anthropometer according to Martin).

\section{Evaluation of explosive power}

Jumps are usually applied for the purpose of testing explosive power, due to the short duration and intensity of movement (Cormie, Mcguigan, \& Newton, 2011; Jezdimirović, Joksimović, Stanković, \& Bubanj (2013). The sample of the measuring instruments used to evaluate explosive power included a set of two tests (Bosco, Luhtanen, \& Komi, 1983): the 
countermovement jump (CMJ) and the countermovement jump with arm swing (CMJAS). All participants were asked to perform three maximal jumps of each test with $30 \mathrm{~s}$ pauses between each repetition and 5 min breaks between the performances of each individual test. The evaluation of vertical jumping was carried out on a flat surface using a system of electric photocells (Optojump, Microgate, Bolzano, Italy) which displayed excellent validity and reliability when testing these types of jumps (Glatthorn et al., 2011) and the highest jump of the three was taken as data for the statistical analysis of each jump.

\section{Evaluation of speed}

The participants were required to perform three maximum effort sprints of 20 meters (Mendez-Villanueva et al., 2011). The participants performed three sprints separated by 3 minutes of rest and the fastest performance was included as data for the statistical analysis. A system of photocells was set at the starting line and at a distance of $20 \mathrm{~m}$ (Witty, System, Microgate, Bolzano, Italy). The system of photocells was set at hip height for all the participants so as to ensure that only one part of the participant's body passed through the gate (Yeadon, Kato, \& Kerwin, 1999).

\section{The evaluation of agility}

The evaluation of agility was carried out using the slalom test, with and without the ball (Sporiš, Jukić, Milanović, \& Vučetić, 2010). The test was described previously by a group of authors (Milanović, Sporiš, Trajković, James, \& Šamija, 2013). Six cones were set up $2 \mathrm{~m}$ apart, the first cone $1 \mathrm{~m}$ away from the starting line. The player started to run as fast as possible constantly changing direction from right to left, and after he reached the last cone the player made an $180^{\circ}$ turn and went on running the slalom back to the starting line. Measurements of the results were carried out using a system of photocells (Witty, System, Microgate, Bolzano, Italy), while all of the equipment was set up according to the guidelines and recommendations of authors who worked with these systems of tracking results (Yeadon et al., 1999).

\section{Statistical analysis}

The statistical analysis included descriptive statistics, a univariate analysis of variance with repeated measures (ANOVA) and the Bonferroni post-hoc test in order to determine whether there was a statistically significant difference between the groups on the tests. Main \pm standard deviation was calculated for all the variables of the experimental and control groups. The magnitude of differences between the experimental and control groups in the initial, transit and final measurement was measured with effect size (ES) analyses and interpreted as: trivial $\leq 0.20$; small $=0.2-0.59$; moderate $=0.60-1.19$; large = 1.20-1.99; very large $\geq 2.0$ (Hopkins, Marshall, Batterham, \& Hanin, 2009). An effect was deemed unclear if the confidence intervals overlapped the threshold for substantial positive and negative values ( \pm 0.20 standardized units) (Hopkins et al., 2009). The level of statistical significance was set at $\mathrm{p}<0.05$, an all of the data were processed using the statistical package IBM SPSS (version 22.0; Inc., Chicago, IL, USA). 


\section{RESULTS}

Table 1 presents the values of body composition and muscle fitness of all the participants in the experimental group and shows the results of the ANOVA which indicates the differences between the testing sessions. No significant differences were observed in the experimental group between TS1 and TS2 except in the variable $20 \mathrm{~m}$ sprint $(3.05 \pm 0.12$ vs $3.10 \pm 0.14)$. However, significant differences were found between TS1 and TS3 in body mass $(66.03 \pm 8.18$ vs $66.69 \pm 7.83)$, body fat mass $(8.26 \pm 2.45$ vs $8.95 \pm 2.57)$, BMI $(21.42 \pm 1.81$ vs $21.64 \pm 1.69)$ and the $20 \mathrm{~m}$ sprint $(3.05 \pm 0.12$ vs $3.14 \pm 0.13)$. Between TS2 and TS3 significant differences were found in body mass $(66.11 \pm 7.99$ vs $66.69 \pm 7.83)$ and BMI (21.44 \pm 1.73 vs $21.64 \pm 1.69)$. There were no significant differences in the jumping performance or agility test in any testing sessions in the experimental group

Table 1 The differences between the testing sessions - the experimental group

\begin{tabular}{|c|c|c|c|c|}
\hline Variables & TS1 & TS2 & TS3 & $\begin{array}{c}\text { ANOVA } \\
p\end{array}$ \\
\hline Body mass (kg) & $66.03 \pm 8.18$ & $66.11 \pm 7.99$ & $66.69 \pm 7.83^{\mathrm{ab}}$ & 0.003 \\
\hline Body fat mass $(\mathrm{kg})$ & $8.26 \pm 2.45$ & $8.54 \pm 2.51$ & $8.95 \pm 2.57^{\mathrm{a}}$ & 0.002 \\
\hline BMI $\left(\mathrm{kg} / \mathrm{m}^{2}\right)$ & $21.42 \pm 1.81$ & $21.44 \pm 1.73$ & $21.64 \pm 1.69^{\mathrm{ab}}$ & 0.004 \\
\hline $\mathrm{CMJ}(\mathrm{cm})$ & $33.76 \pm 2.75$ & $33.79 \pm 2.97$ & $33.48 \pm 2.69$ & 0.555 \\
\hline CMJ AS (cm) & $40.50 \pm 3.46$ & $40.09 \pm 3.20$ & $40.24 \pm 2.93$ & 0.383 \\
\hline $20 \mathrm{~m}$ sprint $(\mathrm{s})$ & $3.05 \pm 0.12$ & $3.10 \pm 0.14^{\mathrm{a}}$ & $3.14 \pm 0.13^{\mathrm{a}}$ & 0.000 \\
\hline Slalom test (s) & $5.88 \pm 0.11$ & $5.81 \pm 0.30$ & $5.82 \pm 0.18$ & 0.225 \\
\hline Slalom test with a ball (s) & $9.88 \pm 0.81$ & $9.84 \pm 0.67$ & $9.83 \pm 0.68$ & 0.935 \\
\hline
\end{tabular}

CMJAS (39.64 \pm 4.60 vs $36.95 \pm 4.20)$ and the $20 \mathrm{~m}$ sprint $(3.07 \pm 0.10$ vs $3.16 \pm 0.14)$. Between TS2 and TS3, significant differences were found in body mass (69.91 \pm 7.84 vs $70.73 \pm 7.92)$, body fat mass $(10.37 \pm 2.50$ vs $11.27 \pm 2.39)$, BMI $(21.97 \pm 1.58$ vs $22.23 \pm 1.55)$ and CMJ (31.89 \pm 3.65 vs $30.96 \pm 3.48)$. There were no significant differences for the agility test in any testing sessions.

Table 2 The differences between the testing sessions - the control group

\begin{tabular}{lrrcc}
\hline Variables & \multicolumn{1}{c}{ TS1 } & TS2 & TS3 & ANOVA \\
& & & & p \\
\hline Body mass (kg) & $69.15 \pm 7.72$ & $69.91 \pm 7.84^{\mathrm{a}}$ & $70.73 \pm 7.92^{\mathrm{ab}}$ & $\mathbf{0 . 0 0 0}$ \\
Body fat mass (kg) & $9.19 \pm 2.13$ & $10.37 \pm 2.50^{\mathrm{a}}$ & $11.27 \pm 2.39^{\mathrm{ab}}$ & $\mathbf{0 . 0 0 0}$ \\
BMI (kg/m ${ }^{2}$ ) & $21.73 \pm 1.57$ & $21.97 \pm 1.58^{\mathrm{a}}$ & $22.23 \pm 1.55^{\mathrm{ab}}$ & $\mathbf{0 . 0 0 0}$ \\
CMJ (cm) & $33.15 \pm 3.61$ & $31.89 \pm 3.65^{\mathrm{a}}$ & $30.96 \pm 3.48^{\mathrm{ab}}$ & $\mathbf{0 . 0 0 0}$ \\
CMJ AS (cm) & $39.64 \pm 4.60$ & $37.69 \pm 4.67^{\mathrm{a}}$ & $36.95 \pm 4.20^{\mathrm{a}}$ & $\mathbf{0 . 0 0 0}$ \\
20m sprint (s) & $3.07 \pm 0.10$ & $3.12 \pm 0.10^{\mathrm{a}}$ & $3.16 \pm 0.14^{\mathrm{a}}$ & $\mathbf{0 . 0 0 0}$ \\
Slalom test (s) & $5.90 \pm 0.15$ & $5.93 \pm 0.24$ & $5.90 \pm 0.26$ & 0.845 \\
Slalom test with a ball (s) & $9.99 \pm 0.34$ & $9.98 \pm 0.67$ & $9.89 \pm 0.57$ & 0.762 \\
\hline
\end{tabular}

Legend: ${ }^{\mathrm{a}}$ - significant change from TS1; ${ }^{\mathrm{b}}$ - significant change from TS2;

TS1 - initial measurement; TS2 - transit measurement; TS3 - final measurement 
Based on the result in Table 2 which contains the values for all the participants in the control group, significant differences were found between TS1 and TS2 in body mass $(69.15 \pm 7.72$ vs $69.91 \pm 7.84)$, body fat mass $(9.19 \pm 2.13$ vs $10.37 \pm 2.50)$, BMI $(21.73 \pm 1.57$ vs $21.97 \pm 1.58)$, CMJ $(33.15 \pm 3.61$ vs $31.89 \pm 3.65)$, CMJAS $(39.64 \pm 4.60$ vs $37.69 \pm 4.67)$ and the $20 \mathrm{~m}$ sprint $(3.07 \pm 0.10$ vs $3.12 \pm 0.10)$. Significant differences were found between TS1 and TS3 in body mass $(69.15 \pm 7.72$ vs70.73 \pm 7.92$)$, body fat mass $(9.19 \pm 2.13$ vs 11.27 \pm 2.39$)$, BMI (21.73 \pm 1.57 vs $22.23 \pm 1.55)$, CMJ (33.15 \pm 3.61 vs $30.96 \pm 3.48)$,

Table 3 presents the differences between the experimental and control group in all the testing sessions. There were no significant differences between the EG and CG at the initial measurement. Significant differences between EG and CG at the transit measurement were found in body fat mass $\mathrm{p}=0.015$ ( $\mathrm{ES}=-0.73$, moderate) and CMJAS $\mathrm{p}=0.043$ (ES=0.60, moderate). The effect size shows small significant decreases in body mass (ES=-0.48, small), $\mathrm{CMJ}$ (ES=0.55, small) and the slalom test $(\mathrm{ES}=-0.44$, small). Significant differences between the EG and CG at the final measurement were found in body fat mass $\mathrm{p}=0.002$ ( $\mathrm{ES}=-0.93$, moderate), $\mathrm{CMJ} \mathrm{p}=0.007$ ( $\mathrm{ES}=0.81$, moderate) and CMJAS $\mathrm{p}=0.003$ ( $\mathrm{ES}=0.91$, moderate). The effect size shows small significant decreases in the body mass (ES=-0.51, small) and slalom test $(\mathrm{ES}=0.40$, small $)$.

Table 3 The differences between the experimental and control group in all the testing sessions

\begin{tabular}{|c|c|c|c|c|c|}
\hline \multicolumn{6}{|c|}{ Initial measurement } \\
\hline Variables & EG & $\mathrm{CG}$ & $\mathrm{MD}$ & $\mathrm{p}$ & $E S(95 \% C I)$ \\
\hline Body mass (kg) & $66.03 \pm 8.18$ & $69.15 \pm 7.72$ & -3.12 & 0.181 & $-0.39(-0.96 \text { to } 0.19)^{\dagger}$ \\
\hline Body fat mass $(\mathrm{kg})$ & $8.26 \pm 2.45$ & $9.19 \pm 2.13$ & -0.93 & 0.130 & $-0.41(-0.97 \text { to } 0.17)^{\dagger}$ \\
\hline BMI $\left(\mathrm{kg} / \mathrm{m}^{2}\right)$ & $21.42 \pm 1.81$ & $21.73 \pm 1.57$ & -0.32 & 0.514 & $-0.18(-0.75$ to 0.39$)$ \\
\hline $\mathrm{CMJ}(\mathrm{cm})$ & $33.76 \pm 2.75$ & $33.15 \pm 3.61$ & 0.61 & 0.515 & $0.19(-0.38$ to 0.75$)$ \\
\hline CMJ AS (cm) & $40.50 \pm 3.46$ & $39.64 \pm 4.60$ & 0.86 & 0.472 & $0.21(-0.36$ to 0.78$)$ \\
\hline $20 \mathrm{~m}$ sprint (s) & $3.05 \pm 0.12$ & $3.07 \pm 0.10$ & -0.02 & 0.566 & $-0.18(-0.75$ to 0.39$)$ \\
\hline Slalom test (s) & $5.88 \pm 0.11$ & $5.90 \pm 0.15$ & -0.02 & 0.508 & $-0.15(-0.72$ to 0.42$)$ \\
\hline Slalom test with a ball (s) & $9.88 \pm 0.81$ & $9.99 \pm 0.34$ & -0.11 & 0.538 & $-0.19(-0.75$ to 0.38$)$ \\
\hline \multicolumn{6}{|c|}{ Transit measurement } \\
\hline Variables & EG & $\mathrm{CG}$ & $\mathrm{MD}$ & $\mathrm{p}$ & $E S(95 \% C I)$ \\
\hline Body mass (kg) & $66.11 \pm 7.99$ & $69.91 \pm 7.84$ & -3.80 & 0.103 & $-0.48(-1.05 \text { to } 0.10)^{\dagger}$ \\
\hline Body fat mass (kg) & $8.54 \pm 2.51$ & $10.37 \pm 2.50$ & -1.83 & 0.015 & $-0.73(-1.30 \text { to }-0.14)^{*}$ \\
\hline $\operatorname{BMI}\left(\mathrm{kg} / \mathrm{m}^{2}\right)$ & $21.44 \pm 1.73$ & $21.97 \pm 1.58$ & -0.53 & 0.266 & $-0.32(-0.88$ to 0.25$)$ \\
\hline $\mathrm{CMJ}(\mathrm{cm})$ & $33.79 \pm 2.97$ & $31.89 \pm 3.65$ & 1.90 & 0.063 & $0.55(-0.04 \text { to } 1.12)^{\dagger}$ \\
\hline CMJ AS (cm) & $40.09 \pm 3.20$ & $37.69 \pm 4.67$ & 2.40 & 0.043 & $0.60(0.01 \text { to } 1.17)^{* \ddagger}$ \\
\hline $20 \mathrm{~m}$ sprint (s) & $3.10 \pm 0.14$ & $3.12 \pm 0.10$ & -0.02 & 0.572 & $-0.16(-0.73$ to 0.41$)$ \\
\hline Slalom test (s) & $5.81 \pm 0.30$ & $5.93 \pm 0.24$ & -0.12 & 0.112 & $-0.44(-1.01 \text { to } 0.14)^{\dagger}$ \\
\hline Slalom test with a ball (s) & $9.84 \pm 0.67$ & $9.98 \pm 0.67$ & -0.14 & 0.490 & $-0.21(-0.77$ to 0.36$)$ \\
\hline \multicolumn{6}{|c|}{ Final measurement } \\
\hline Variables & EG & $\mathrm{CG}$ & MD & $\mathrm{p}$ & $E S(95 \% C I)$ \\
\hline Body mass (kg) & $66.69 \pm 7.83$ & $70.73 \pm 7.92$ & -4.04 & 0.082 & $-0.51(-1.08 \text { to } 0.07)^{\dagger}$ \\
\hline Body fat mass (kg) & $8.95 \pm 2.57$ & $11.27 \pm 2.39$ & -2.32 & 0.002 & $-0.93(-1.51 \text { to }-0.32)^{* \dagger}$ \\
\hline $\mathrm{BMI}\left(\mathrm{kg} / \mathrm{m}^{2}\right)$ & $21.64 \pm 1.69$ & $22.23 \pm 1.55$ & -0.58 & 0.192 & $-0.36(-0.93$ to 0.21$)$ \\
\hline $\mathrm{CMJ}(\mathrm{cm})$ & $33.48 \pm 2.69$ & $30.96 \pm 3.48$ & 2.52 & 0.007 & $0.81(0.21 \text { to } 1.39)^{* *}$ \\
\hline CMJ AS (cm) & $40.24 \pm 2.93$ & $36.95 \pm 4.20$ & 3.29 & 0.003 & $0.91(0.30 \text { to } 1.49)^{* *}$ \\
\hline $20 \mathrm{~m}$ sprint (s) & $3.14 \pm 0.13$ & $3.16 \pm 0.14$ & -0.02 & 0.683 & $-0.02(-0.59$ to 0.55$)$ \\
\hline Slalom test (s) & $5.82 \pm 0.18$ & $5.90 \pm 0.26$ & -0.08 & 0.204 & $-0.40(-0.97 \text { to } 0.18)^{\dagger}$ \\
\hline Slalom test with a ball (s) & $9.83 \pm 0.68$ & $9.89 \pm 0.57$ & -0.06 & 0.742 & $-0.10(-0.66$ to 0.47$)$ \\
\hline
\end{tabular}

Legend: EG - experimental group; CG - control group; MD - main difference; ES - effect size;

$\mathrm{CI}$ - confidence interval; $\dagger$ - small; $\ddagger$ - moderate 


\section{DISCUSSION}

The aim of this research was to examine the effects of a 6-week detraining on body composition and muscle fitness during the off-season period between the young soccer players who spent their transition period passively and those who practiced at least three times a week, including high-intensity interval training, strength exercise training and training of small side games. The off-season period is very useful for players and coaches to recover and to "prepare" for the following season (Silva, Brito, Akenhead, \& Nassis, 2016).

Based on the present findings, during the off-season period soccer players add extra kilograms of body fat mass and decrease their physical parameters. The soccer players that followed the special training program achieved lower results of body measurements compared to the players that did not follow any organized training program. At the end of the 2-week and 6-week detraining period, significant increases in body mass, body fat mass and BMI were evident in the control group. These results were similar to those mentioned by other researchers (Ostojić, 2003; Hoshikawa et al., 2005; Reinke et al., 2009). No significant differences in body composition were observed after 2 weeks in the experimental group, but after 6 weeks of detraining significant increases in all variables of body composition were evident. An increase in body mass and body fat mass which has been observed after the off-season period is consistent with the other literature (Sotiropoulos, Travlos, Gissis, Souglis, \& Grezios, 2009; Koundourakis et al., 2014; Requena et al., 2017). Significant differences between two groups ware found in body fat mass $\mathrm{p}=0.015$ (ES=-0.73, moderate) after a 2-week program and after a 6-week in the same variable $\mathrm{p}=0.002$ ( $\mathrm{ES}=-0.93$, moderate). The increased body mass in our study could be attributed to reduced training stress during the detraining period. All of the above studies were performed including adult soccer players in contrast with our study where the participants were young soccer players. Unlike in our study, other authors reported that after 4 weeks of detraining there were no significant differences in body mass between the measurements of youth soccer players (Vassilis et al., 2019). In addition, one study reported non-significant differences in body mass and the BMI between the initial and final measurement of young soccer players after 6 weeks of detraining (Melchiorri et al., 2015).

Vertical jumping and sprinting performance show significant differences in CMJ, CMJAS and the $20 \mathrm{~m}$ sprint in the control group after 2 weeks and 6 weeks of detraining. These findings are in agreement with the previous study (Caldwell \& Peters, 2009). In the experimental group, vertical jumping performance did not change between the three testing sessions performed, but sprinting performance has a significant increase. These findings are in agreement with the other studies in young soccer players (Amigo, Cadefau, Ferrer, Tarrados, \& Cusso, 1998) and semi-professional players (Caldwell \& Peters, 2009). Significant differences between two groups ware found in CMJAS $\mathrm{p}=0.043$ ( $\mathrm{ES}=0.60$, moderate) after a 2-week training program and after a a6-week $\mathrm{p}=0.003$ (ES=-0.91, moderate) and $\mathrm{CMJ} \mathrm{p}=0.007$ ( $\mathrm{ES}=0.81$, moderate) after 6 -week. These results are similar to those of previous studies (Ostojić, 2003; Caldwell \& Peters, 2009; Koundourakis et al., 2014). Nevertheless, some studies (Requena et al., 2017) did not find significant changes in vertical jumping between the groups. There were no significant differences in sprinting performance between the groups in any testing sessions and these findings are in agreement with some studies (Requena et al., 2017). Unlike our results, the research found a significant decrease in the $20 \mathrm{~m}$ sprint after the off-season period (Koundourakis et al., 2014). The results of this study demonstrated that the players in the experimental and the control groups did not show a significant increase or decrease on the agility test (the slalom test and slalom test with a ball) within a 6-week time period. 


\section{CONCLUSION}

The results of this study showed that the amount of body fat increased as vertical jumping decreased after a specified training program lasting 6 weeks during the offseason period. Obviously, the players from the experimental group demonstrated better values of maintaining their sports form. A 6-week training program period including high intensity interval training, strength exercises and training involving small sides games, as used in this study, seems sufficient to maintain physical parameters and parameters of body composition (not after 6 weeks) of players and to let them start the preseason period with a good level of physical fitness. This study also provides useful information for coaches to design a special training program to maintain physical performance and stop changes in body composition in the off-season period and avoid very long periods of complete rest (no more than 2 weeks) at the end of the season.

\section{REFERENCES}

Amigo, N., Cadefau, J.A., Ferrer, I., Tarrados, N., \& Cusso, R. (1998). Effect of summer intermission on skeletal muscle of adolescent soccer players. The Journal of Sports Medicine and Physical Fitness, 38(4), 298-304.

Bosco, C., Luhtanen, P., \& Komi, P.V. (1983). A simple method for measurement of mechanical power in jumping. European Journal of Applied Physiology and Occupational Physiology, 50(2), 273-282.

Caldwell, B.P., \& Peters, D.M. (2009). Seasonal variation in physiological fitness of a semiprofessional soccer team. The Journal of Strength and Conditioning Research, 23(5), 1370-1377.

Carbuhn, A.F., Fernandez, T.E., Bragg, A.F., Green, J.S., \& Crouse, S.F. (2010). Sport and training influence bone and body composition in women collegiate athletes. The Journal of Strength and Conditioning Research, 24(7), 1710-1717.

Cormie, P., Mcguigan, M.R., \& Newton, R.U. (2011). Developing maximal neuromuscular power: part 2training considerations for improving maximal power production. Sports Medicine, 41(2), 125-146.

García-Pallarés, J., García-Fernández, M., Sánchez-Medina, L., \& Izquierdo, M. (2010). Performance changes in world-class kayakers following two different training periodization models. European Journal of Applied Physiology, 110(1), 99-107.

Glatthorn, J.F., Gouge, S., Nussbaumer, S., Stauffacher, S., Impellizzeri, F.M., \& Maffiuletti, N.A. (2011). Validity and reliability of Optojump photoelectric cells for estimating vertical jump height. The Journal of Strength and Conditioning Research, 25(2), 556-560.

Hopkins, W., Marshall, S., Batterham, A., \& Hanin, J. (2009). Progressive statistics for studies in sports medicine and exercise science. Medicine+ Science in Sports + Exercise, 41(1), 3.

Hoshikawa, Y., Kanno, A., Ikoma, T., Muramatsu, M., Iida, T., Uchiyama, A., et al. (2005). Off-season and pre-season changes in total and regional body composition in Japanese professional soccer league players. In Science and Football V: The Proceedings of the Fifth World Congress on Sports Science and Football, (p. 165). Routledge.

Izquierdo, M., Ibañez, J., Gonzalez-Badillo, J.J., Ratamess, N.A., Kraemer, W.J., Häkkinen, K., et al. (2007). Detraining and tapering effects on hormonal responses and strength performance. The Journal of Strength and Conditioning Research, 21(3), 768-775

Jezdimirović, M., Joksimović, A., Stanković, R., \& Bubanj, S. (2013). Differences in the vertical jump in soccer players according to their position on the team. Facta Universitatis Series Physical Education and Sport, 11(3), 221-226.

Koundourakis, N.E., Androulakis, N.E., Malliaraki, N., Tsatsanis, C., Venihaki, M., \& Margioris, A.N. (2014). Discrepancy between exercise performance, body composition, and sex steroid response after a six-week detraining period in professional soccer players. PloS one, 9(2), e87803.

Kraemer, W.J., French, D.N., Paxton, N.J., Häkkinen, K., Volek, J.S., Sebastianelli, et al. (2004). Changes in exercise performance and hormonal concentrations over a big ten soccer season in starters and nonstarters. Journal of Strength and Conditioning Research, 18(1), 121-128.

Kutlu, M., Yapıc1, H., Yoncalık, O., \& Çelik, S. (2012). Comparison of a new test for agility and skill in soccer with other agility tests. Journal of Human Kinetics, 33(1), 143-150. 
Little, T., \& Williams, A.G. (2007). Measures of exercise intensity during soccer training drills with professional soccer players. The Journal of Strength \& Conditioning Research, 21(2), 367-371.

Melchiorri, G., Ronconi, M., Triossi, T., Viero, V., De, D.S., Tancredi, V., et al. (2014). Detraining in young soccer players. The Journal of Sports Medicine and Physical Fitness, 54(1), 27-33.

Mendez-Villanueva, A., Buchheit, M., Kuitunen, S., Douglas, A., Peltola, E., \& Bourdon, P. (2011). Agerelated differences in acceleration, maximum running speed, and repeated-sprint performance in young soccer players. Journal of Sports Sciences, 29(5), 477-484.

Milanović, Z., Sporiš, G., Trajković, N., James, N., \& Šamija, K. (2013). Effects of a 12 week saq training programme on agility with and without the ball among young soccer players. Journal of Sports Science and Medicine, $12(1), 97$.

Minett, M.M., Binkley, T.B., Weidauer, L.A., \& Specker, B.L. (2017). Changes in body composition and bone of female collegiate soccer players through the competitive season and off-season. Journal of Musculoskeletal and Neuronal Interactions, 17(1), 386.

Mujika, I., \& Padilla, S. (2000a). Detraining: Loss of training-induced physiological and performance adaptations. Part I. Sports Medicine, 30(2), 79-87.

Mujika, I., \& Padilla, S. (2000b). Detraining: Loss of training-induced physiological and performance adaptations. Part II: long term insufficient training stimulus. Sports Medicine, 30(3), 145-154.

Ostojić, S.M. (2003). Seasonal alterations in body composition and sprint performance of elite soccer players. Journal of Exercise Physiology Online, 6(3), 11-14.

Reinke, S., Karhausen, T., Doehner, W., Taylor, W., Hottenrott, K., Duda, G.N., et al. (2009). The influence of recovery and training phases on body composition, peripheral vascular function and immune system of professional soccer players. PloS One, 4(3), e4910.

Requena, B., García, I., Suárez-Arrones, L., Saez de Villarreal, E., Naranjo Orellana, J., \& Santalla, A. (2017). Off-season effects on functional performance, body composition, and blood parameters in toplevel professional soccer players. Journal of Strength and Conditioning Research, 31(4), 939-946.

Silva, J.R., Brito, J., Akenhead, R., \& Nassis, G.P. (2016). The transition period in soccer: a window of opportunity. Sports Medicine, 46(3), 305-313.

Slettaløkken, G., \& Rønnestad, B.R. (2014). High-intensity interval training every second week maintains $\mathrm{V}$ [combining dot above] $\mathrm{O} 2_{\max }$ in soccer players during off-season. The Journal of Strength \& Conditioning Research, 28(7), 1946-1951.

Sotiropoulos, A., Travlos, A.K., Gissis, I., Souglis, A.G., \& Grezios, A. (2009). The effect of a 4-week training regimen on body fat and aerobic capacity of professional soccer players during the transition period. The Journal of Strength and Conditioning Research, 23(6), 1697-1703.

Sporiš, G., Jukić, I., Milanović, L., \& Vučetić, V. (2010). Reliability and factorial validity of agility tests for soccer players. The Journal of Strength and Conditioning Research, 24(3), 679-686.

Tumilty, D. (1993). Physiological characteristics of elite soccer players. Sports Medicine, 16(2), 80-96.

Vassilis, S., Yiannis, M., Athanasios, M., Dimitrios, M., Ioannis, G., \& Thomas, M. (2019). Effect of a 4week detraining period followed by a 4-week strength program on isokinetic strength in elite youth soccer players. Journal of Exercise Rehabilitation, 15(1), 67.

Yeadon, M.R., Kato, T., \& Kerwin, D.G. (1999). Measuring running speed using photocells. Journal of Sports Sciences, 17(3), 249-257.

\section{PROMENE U TELESNOJ KOMPOZICIJI I MIŠIĆNOM FITNESU TOKOM PRELAZNOG PERIODA MLADIH FUDBALERA}

Cilj ovog istraživanja je da se ispitaju efekti 6-nedeljnog prelaznog perioda na telesnu kompoziciju $i$ mišićnom fitnesu mladih fudbalera. Ukupno 48 mladih fudbalera, nasumično podeljenih $u$ eksperimentalnu grupu-EG (n=24; uzrast: $16.83 \pm 1.14$ godina; visina: $175.35 \pm 6.68 \mathrm{~cm}) i$ kontrolnu grupu-CG ( $n=24$; uzrast: $16.80 \pm 1.19$ godina; visina: $178.18 \pm 6.97 \mathrm{~cm})$ učestvovalo je u ovom istraživanju. Varijable za procenu telesne kompozicije (telesna težina, telesne masti i BMI) i mišićnog fitnesa (CMJ, CMJAS, $20 \mathrm{~m}$ sprint, slalom test i slalom test sa loptom) su mereni. Prvo testiranje (TS1) obavljeno je neposredno nakon završetka takmičarskog perioda. Drugo testiranje (TS2) je bilo nakon 2-nedelje i treće testiranje (TS3) je bilo nakon 6-nedelja na početku pripremnog perioda. Na osnovu statističke analize (ANOVA sa ponovljenim merenjima) statistička značajnost je pronađena posle TS2 $i$ TS3 u svim varijablama $(p<0.05)$ osim u varijablama agilnosti (slalom test and slalom 
test sa loptom) kontrolne grupe. Statistička značajnost eksperimentalne grupe posle TS2 pronađena je samo u varijabli $20 \mathrm{~m}$ sprint ( $p<0.05)$, a posle TS3 u telesnoj težini $(p<0.05)$, telesnim mastima $(p<0.05), B M I(p<0.05) i 20 m$ sprint $(p<0.05)$. Analiza veličine efekta pokazala nam je značajna smanjenja posle TS2 između EG i CG u varijabli telesnih masti (ES=-0.73, umerena) $i$ značajna uvećanja u varijabli CMJAS (ES=0.60, umerena). Značajna smanjenja posle TS3 između EG $i C G$ je pronađeno $u$ varijabli telesne masti $(E S=-0.93$, umerena) $i$ značajna uvećanja u oba parametra skakčkih sposobnosti $C M J(E S=0.81$, umerena) $i$ CMJAS $(E S=0.91$, umerena).

Ključne reči: telesna kompozicija, mišićni fitness, prelazni period, prestanak treniranja 